\title{
IN VITRO CELL CYTOTOXICITY AND WOUND HEALING ACTIVITY OF TOPICAL FILM FORMING HYDROGEL OF PAPAIN UREA IN VERO CELLS
}

${ }^{* 1}$ Mrs. R. Sruthi,

Post graduate student, Department of Pharmaceutics, Periyar College of Pharmaceutical Sciences, Tiruchirapalli, Tamil Nadu, India

E-Mail Id: sruthirajan1997@gmail.com

\section{${ }^{2}$ Dr. S.P.Senthil}

Guide, Head, Department of Pharmaceutics, Periyar College of Pharmaceutical Sciences, Tiruchirapalli, Tamil Nadu, India

\section{E-Mail Id: senthilumasenthil@gmail.com}

\section{${ }^{3}$ Dr. R. Senthamarai}

Principal, Department of Pharmacognosy, Periyar College of Pharmaceutical Sciences, Tiruchirapalli, Tamil Nadu, India

E-Mail Id: periyarcps@gmail.com

*Corresponding Author

Mrs. R. Sruthi, Post graduate student, Department of Pharmaceutics, Periyar College of Pharmaceutical Sciences, Tiruchirapalli, Tamil Nadu, India

Type of Publication

Original Research Article 


\begin{abstract}
Wounds, whether acute or chronic, are one of the most common health problems worldwide, and medicative drugs are frequently used in wound healing. More research into wound treatment is being conducted at a rapid pace. For some wound types, enzymatic debridement of nonviable tissue remains the most effective debridement option. In theory, topical enzymes have been used in this therapy to remove necrotic tissue in the wound bed by digesting and dissolving the devitalized tissue. Papain, a plant-derived enzyme with a long history of clinical success, is one of these enzymes. The formulation of papain urea film forming gel is being used for wound repair. Vero cells were assessed in vitro for cell cytotoxicity and wound healing activity. When compared with the control, the results demonstrate significant healing activity and wound closure area. As a result of the findings of the study, the current formulation appears to be effective in healing wounds in in-vitro experiments.
\end{abstract}

Keywords: Wound healing, Papain urea, enzymatic debridement, Cell Cytotoxicity, Vero cells

\title{
INTRODUCTION: [1-4]
}

A wound is any type of skin damage or breakage caused by a medical, physiological disease, or trauma. When an injured or wounded tissue returned to its prior or natural anatomical form, structure, as well as function within a reasonable time frame, it is rendered completely recovered. Wounds are categorized as follows relying on the defected skin component and also the number of skin layers.

- In Superficial wounds, the epidermis is damaged.

- Partial thickness wounds encompass both the epidermal and deeper dermal layers.

- Deeper tissues, along with subcutaneous layers, are observable in full thickness wounds.

Wounds are often categorized as follows:
a. Acute wounds
b. Chronic wounds
c. Complicated wounds

Most wounds heal on their own, so treatment for such wounds is limited to safeguarding them from the environment. Nevertheless, for non healing wounds, a more effective healingpromoting treatment is necessary. As a result, wound care is determined by the type of wound and also the purpose of treatment. 
Wound healing is a complex as well as dynamic process in which missing cell components and tissue layers are replaced. Healing is the interaction of a complex cascade of cellular responses that results in the resurfacing, reconstitution, and strength regeneration of damaged tissues. The four major historical phases in wound healing are haemostasis, inflammation, proliferation, and remodelling.

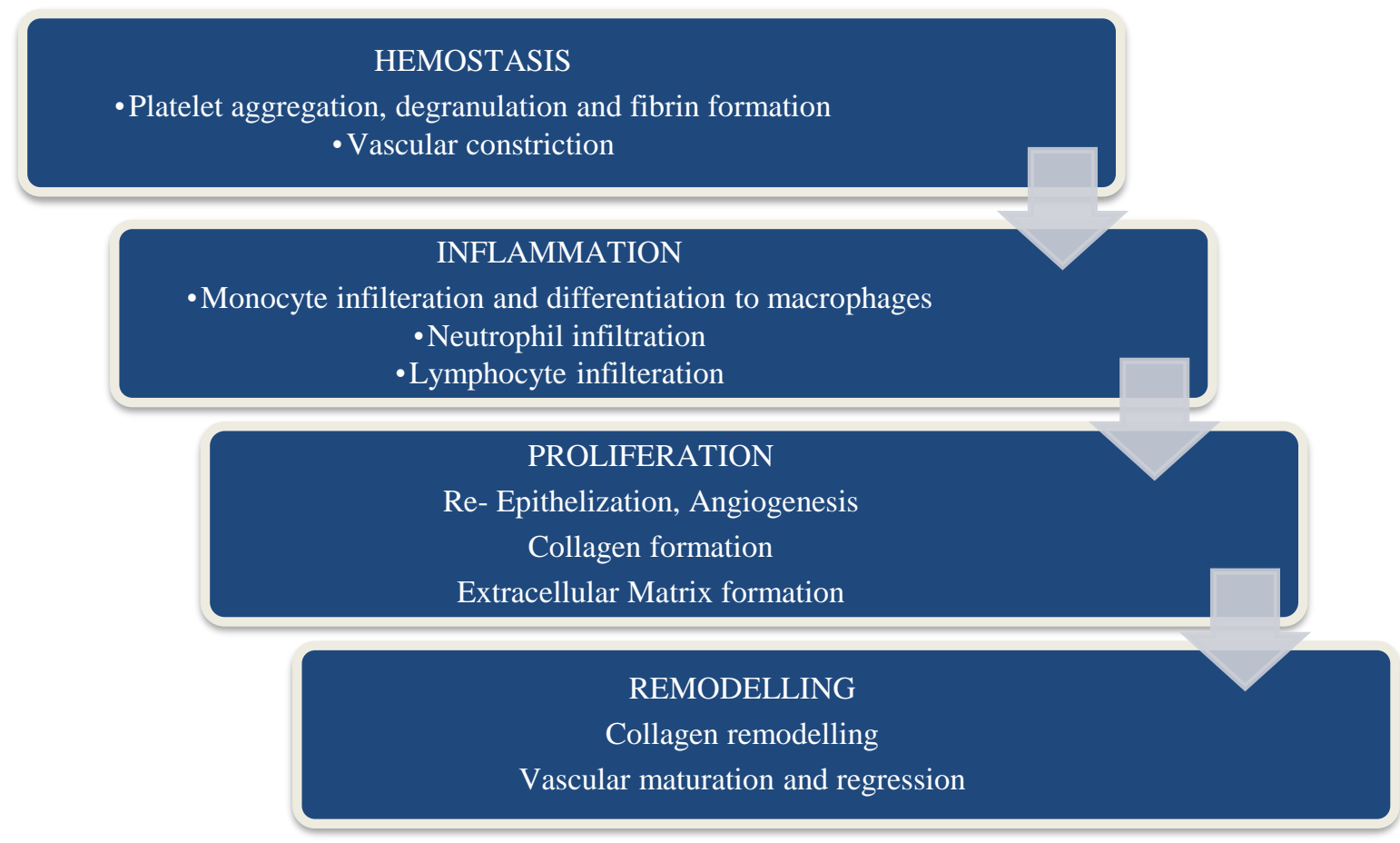

Fig 1: Wound Healing Process

\section{MATERIALS AND METHODS:}

Papain, urea, high molecular weight chitosan was purchased from Sisco Research Laboratories Pvt. Ltd Mumbai. DMEM medium, Fetal Bovine Serum (FBS) and antibiotic solution were from Gibco (USA), DMSO (Dimethyl sulfoxide) and MTT (3-4,5 dimethylthiazol-2yl-2,5-diphenyl tetrazolium bromide) $(5 \mathrm{mg} / \mathrm{ml}$ ) were from Sigma, (USA), 1X PBS was from Himedia, (India), 96 well tissue culture plate and wash beaker were from Tarson (India). DMEM medium, Fetal Bovine Serum (FBS) and antibiotic solution were from Gibco (USA), 1X PBS was from Himedia, (India). 6 well tissue culture plate and wash beaker were from Tarson (India).

The formulation was prepared using simple agitation method. Briefly, the calculated amount of chitosan was added, and dispersed slowly in distilled water with continuous magnetic stirring. Calculated quantity of Papain and urea was mixed together and added to the above solution. Glacial acetic acid was added drop wise for chitosan solubilisation and mixed by 
agitation. Finally a plasticizer propylene glycol and preservative sodium benzoate is added and mixed well. The formulation is subjected to homogenization for uniform dispersion of particles. All procedures were conducted at room temperature.

\section{MTT Assay for Cell Cytotoxicity [5-8]}

\section{Principle}

The MTT (3-4, 5 dimethylthiazol-2yl-2, 5-diphenyl tetrazolium bromide) assay is based on the capacity of a viable cell's mitochondrial dehydrogenase enzyme to cleave the tertrazolium rings of the pale yellow MTT and form a dark blue coloured formazan crystal that is largely impermeable to cell membranes, likely to result in its accumulation within healthy cells. Solubilization of cells with detergents (DMSO) results in the liberation of solubilized crystals. The number of surviving cells is proportional to the amount of formazan product produced. A multi-well plate reader can be used to quantify the colour.

\section{Procedure}

\section{Cell culture}

Vero cells (African green monkey kidney cells) cell line was purchased from NCCS, Pune and cultured in liquid medium (DMEM) supplemented 10\% Fetal Bovine Serum (FBS), 100 $\mathrm{ug} / \mathrm{ml}$ penicillin and $100 \mu \mathrm{g} / \mathrm{ml}$ streptomycin, and maintained under an atmosphere of $5 \%$ $\mathrm{CO}_{2}$ at $37^{\circ} \mathrm{C}$.

\section{MTT Assay}

Using Vero cells, the formulation was tested for in vitro cytotoxicity using the 3-(4,5dimethylthiazol-2-yl)-2,5-diphenyltetrazolium bromide (MTT) assay. In brief, trypsinization was used to harvest Vero cells, which were then pooled in a $15 \mathrm{ml}$ tube. The cells were then plated at a density of 1105 cells/ml cells/well (200 L) into a 96-well tissue culture plate in DMEM medium with $10 \%$ FBS and $1 \%$ antibiotic solution for $24-48$ hours at $37^{\circ} \mathrm{C}$. In a serum-free DMEM medium, the wells were washed with sterile PBS and treated with various concentrations of the formulation. Each sample was replicated three times, and the cells were incubated for $24 \mathrm{hrs}$ at $37^{\circ} \mathrm{C}$ in a humidified $5 \% \mathrm{CO}_{2}$ incubator. 


\section{Wound Healing Assay [5-10]}

Migration is an important property of living cells that is required for normal development, immune response, and disease processes such as cancer metastasis and inflammation. Methods for studying cell migration are extremely necessary and beneficial in many areas of biomedical research, including cancer biology, immunology, vascular biology, cell biology, and developmental biology.

\section{Procedure}

\section{Cell culture}

Vero cells (African Green Monkey Kidney cells) cell line was purchased from National centre for cellular sciences, Pune, and cultured in liquid medium (DMEM) supplemented $10 \%$ Fetal Bovine Serum (FBS), $100 \mu \mathrm{g} / \mathrm{ml}$ penicillin and $100 \mu \mathrm{g} / \mathrm{ml}$ streptomycin, and maintained under an atmosphere of $5 \% \mathrm{CO}_{2}$ at $37^{\circ} \mathrm{C}$.

\section{Wound healing assay}

The wound healing assay was used to assess cell migration after treatment in both cancer and non-cancer cell lines. Vero cells were seeded into a six-well tissue culture dish and grown in complete medium to 90 percent confluency. As outlined, cell monolayers were injured by a plastic tip $(1 \mathrm{~mm})$ that touched the plate. Wounded monolayers were then washed with medium four times to remove cell debris before being incubated in 1 percent FBS medium. The cells were incubated for $24 \mathrm{hrs}$ after being treated with $130 \mathrm{~g} / \mathrm{ml}$ of formulation. Cells were observed using an inverted microscope with a camera. Image-J software was used to measure the wound area (NIH, Bethesda, MD, USA). The wound area percentage was calculated as the wound area of control and treated sample. 
RESULT AND DISCUSSION:

MTT assay Cell Cytotoxicity

Table 1: OD Value at 570 nm

\begin{tabular}{|c|c|c|c|c|}
\hline S. NO & $\begin{array}{l}\text { TESTED SAMPLE } \\
\text { CONCENTRATION }\end{array}$ & \multicolumn{3}{|c|}{$\begin{array}{l}\text { OD VALUE AT } 570 \text { nm } \\
\text { (IN TRIPLICATES) }\end{array}$} \\
\hline 1. & Control & 0.498 & 0.439 & 0.507 \\
\hline 2. & $10 \mu \mathrm{g} / \mathrm{ml}$ & 0.485 & 0.454 & 0.472 \\
\hline 3. & $20 \mu \mathrm{g} / \mathrm{ml}$ & 0.463 & 0.446 & 0.455 \\
\hline 4. & $40 \mu \mathrm{g} / \mathrm{ml}$ & 0.436 & 0.439 & 0.427 \\
\hline 5. & $60 \mu \mathrm{g} / \mathrm{ml}$ & 0.408 & 0.421 & 0.410 \\
\hline 6. & $80 \mu \mathrm{g} / \mathrm{ml}$ & 0.399 & 0.379 & 0.404 \\
\hline 7. & $100 \mu \mathrm{g} / \mathrm{ml}$ & 0.353 & 0.360 & 0.376 \\
\hline 8. & $200 \mu \mathrm{g} / \mathrm{ml}$ & 0.331 & 0.333 & 0.349 \\
\hline 9. & $300 \mu \mathrm{g} / \mathrm{ml}$ & 0.315 & 0.325 & 0.300 \\
\hline 10. & $400 \mu \mathrm{g} / \mathrm{ml}$ & 0.308 & 0.288 & 0.279 \\
\hline 11. & $500 \mu \mathrm{g} / \mathrm{ml}$ & 0.259 & 0.257 & 0.216 \\
\hline
\end{tabular}


Table 2: Cell Viability \% of Formulation

\begin{tabular}{|c|c|c|c|c|c|}
\hline S. NO & $\begin{array}{l}\text { TESTED SAMPLE } \\
\text { CONCENTRATION }\end{array}$ & \multicolumn{3}{|c|}{$\begin{array}{c}\text { CELL VIABILITY (\%) } \\
\text { (IN TRIPLICATES) }\end{array}$} & $\begin{array}{c}\text { MEAN } \\
\text { VALUE }(\%)\end{array}$ \\
\hline 1. & Control & 100 & 100 & 100 & 100 \\
\hline 2. & $10 \mu \mathrm{g} / \mathrm{ml}$ & 97.3896 & 103.417 & 93.0966 & 97.9676 \\
\hline 3. & $20 \mu \mathrm{g} / \mathrm{ml}$ & 92.9719 & 101.595 & 89.7436 & 94.7700 \\
\hline 4. & $40 \mu \mathrm{g} / \mathrm{ml}$ & 87.5502 & 100 & 84.2209 & 90.5903 \\
\hline 5. & $60 \mu \mathrm{g} / \mathrm{ml}$ & 81.9277 & 95.8998 & 80.8679 & 86.2317 \\
\hline 6. & $80 \mu \mathrm{g} / \mathrm{ml}$ & 80.1205 & 86.3326 & 79.6844 & 82.0458 \\
\hline 7. & $100 \mu \mathrm{g} / \mathrm{ml}$ & 70.8835 & 82.0046 & 74.1617 & 75.6832 \\
\hline 8. & $200 \mu \mathrm{g} / \mathrm{ml}$ & 66.4659 & 75.8542 & 68.8363 & 70.3854 \\
\hline 9. & $300 \mu \mathrm{g} / \mathrm{ml}$ & 63.253 & 74.0319 & 59.1716 & 65.4855 \\
\hline 10. & $400 \mu \mathrm{g} / \mathrm{ml}$ & 61.8474 & 65.6036 & 55.0296 & 60.8268 \\
\hline 11. & $500 \mu \mathrm{g} / \mathrm{ml}$ & 52.008 & 58.5421 & 42.6036 & 51.0512 \\
\hline
\end{tabular}

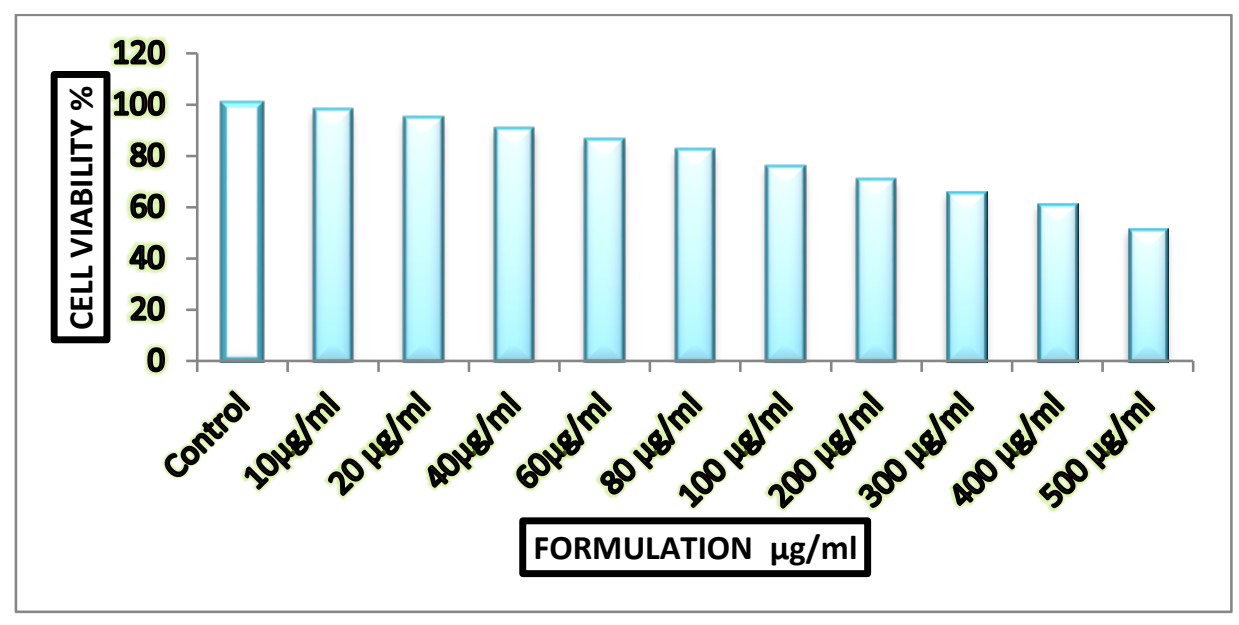

Fig 2: The Effect of Formulation on Vero Cell Viability at Different Concentration 
Table 3: IC50 Value of Formulation: $130.5 \mu \mathrm{g} / \mathrm{ml}$

\begin{tabular}{|c|c|c|}
\hline \multicolumn{3}{|l|}{$\begin{array}{l}\log (\text { inhibitor) vs. Normalize } \\
\text { Variable slope }\end{array}$} \\
\hline \multicolumn{3}{|l|}{ Best-fit values } \\
\hline $\operatorname{LogIC50}$ & & 2.116 \\
\hline HillSlope & & -1.373 \\
\hline IC50 & & 130.5 \\
\hline \multicolumn{3}{|l|}{ Std. Error } \\
\hline $\operatorname{LogIC50}$ & & 0.02611 \\
\hline HillSlope & & 0.1081 \\
\hline \multicolumn{3}{|l|}{ 95\% Confidence Intervals } \\
\hline $\operatorname{LogIC50}$ & & 2.062 to 2.169 \\
\hline HillSlope & & -1.594 to -1.152 \\
\hline IC50 & & 115.4 to 147.6 \\
\hline \multicolumn{3}{|l|}{ Goodness of Fit } \\
\hline Degrees of Freedom & & 28 \\
\hline R square & & 0.9447 \\
\hline Absolute Sum of Squares & & 1660 \\
\hline Sy.x & & 7.699 \\
\hline \multicolumn{3}{|l|}{ Number of points } \\
\hline Analyzed & 3 & 30 \\
\hline
\end{tabular}


Table 4: Images of Control Cells and Formulation Treated Cells

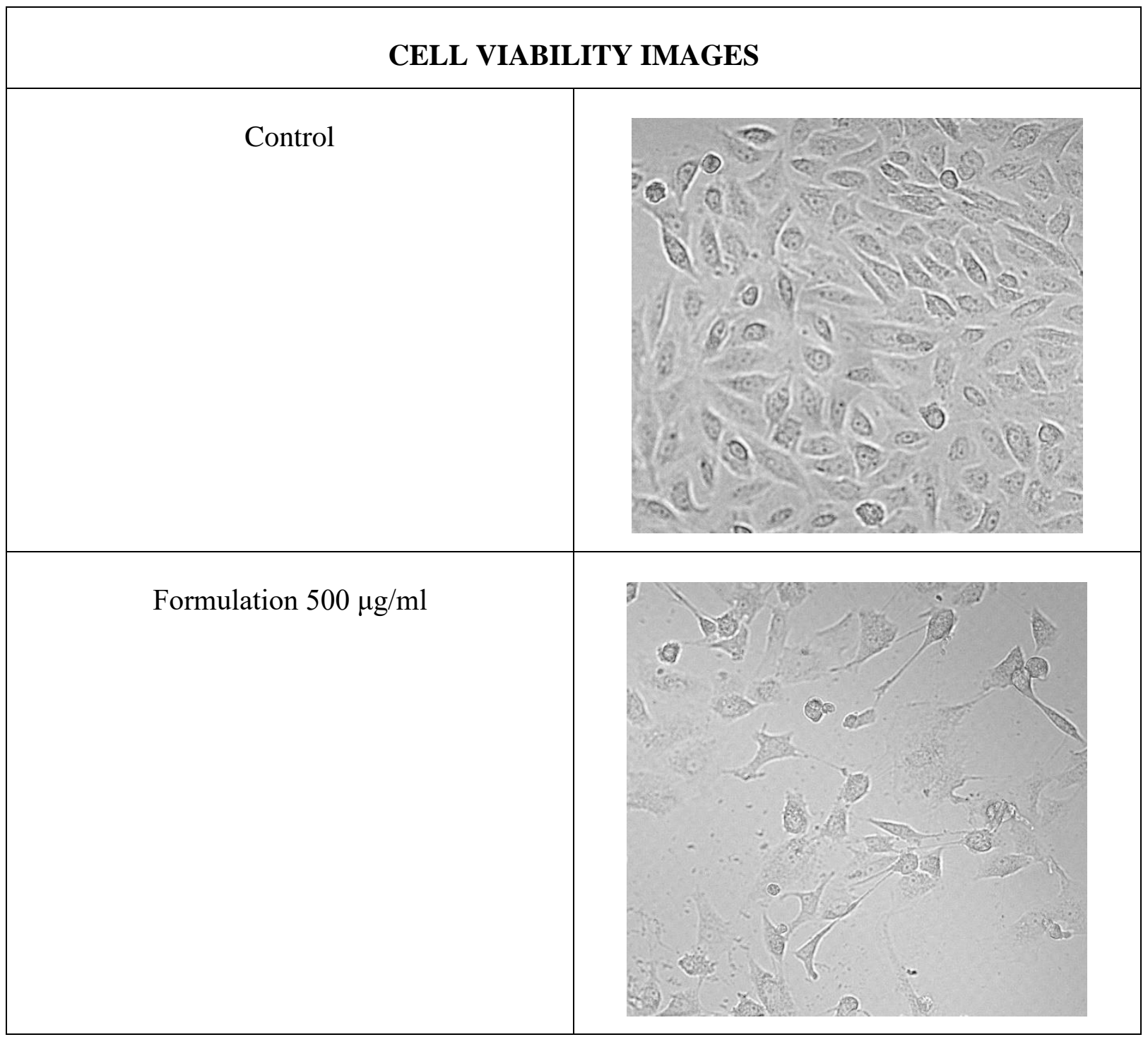


Wound healing assay

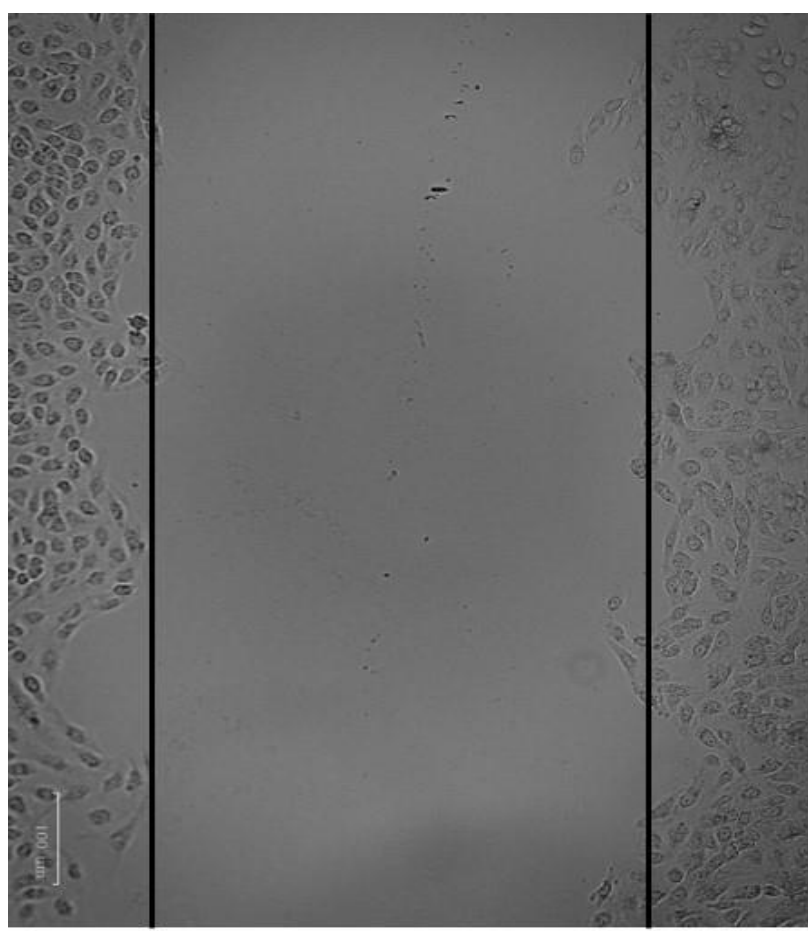

Fig 3: Control Showing

Wound At 0 hrs

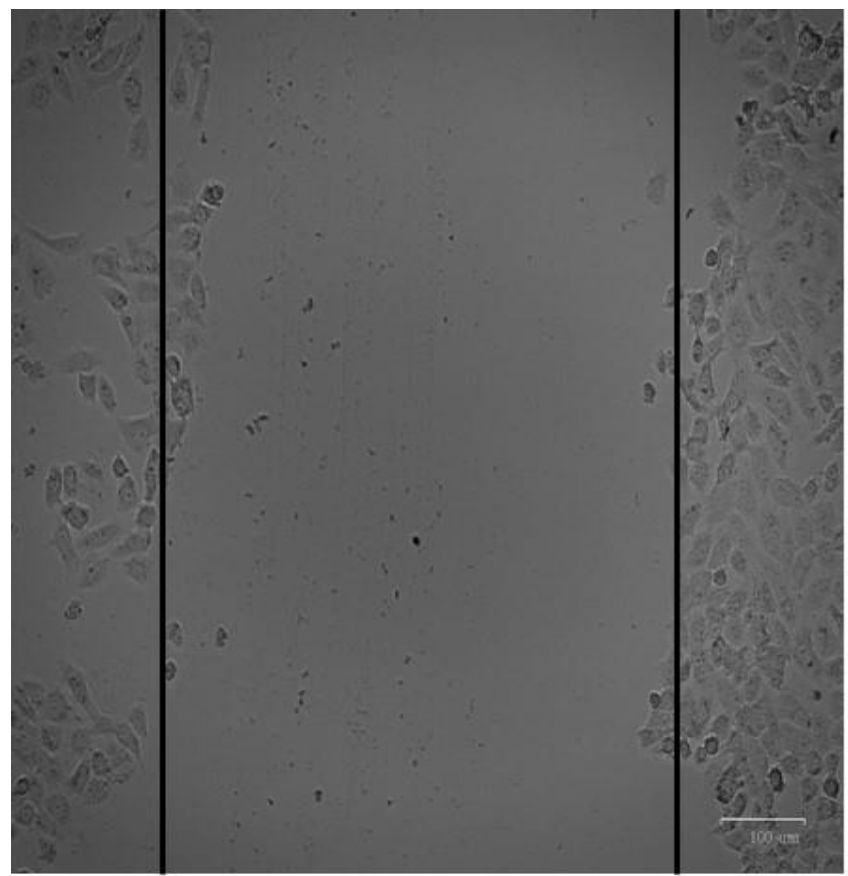

Fig 5: Formulation Showing

Wound At 0 hrs

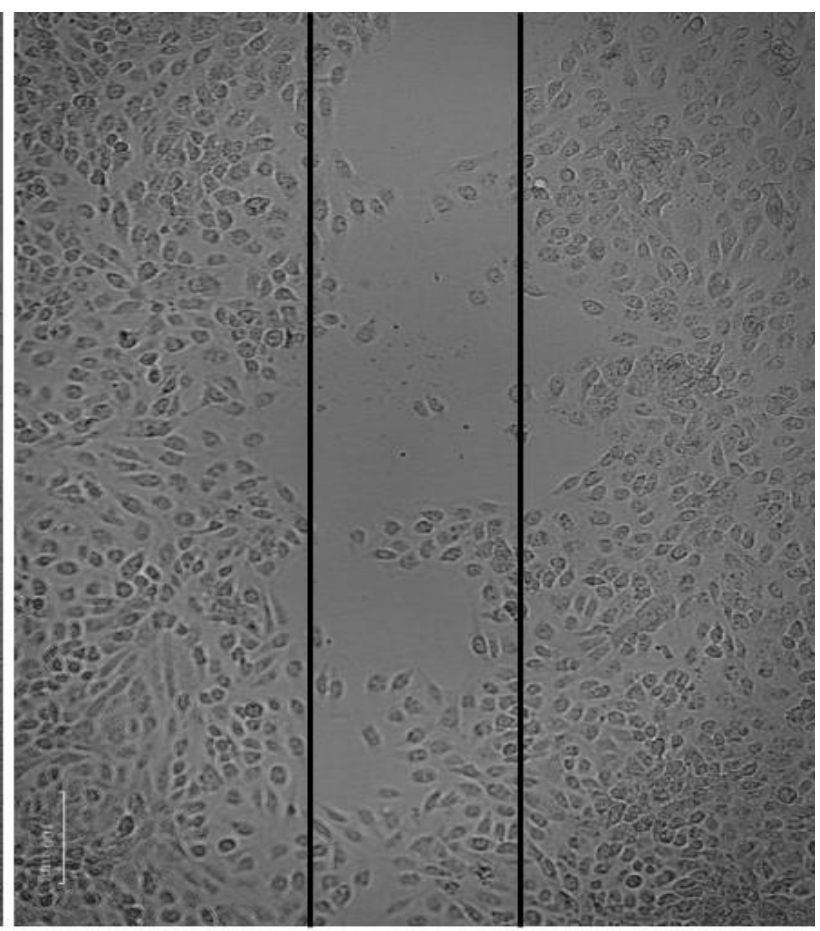

Fig 4: Control Showing

Wound At 24 hrs

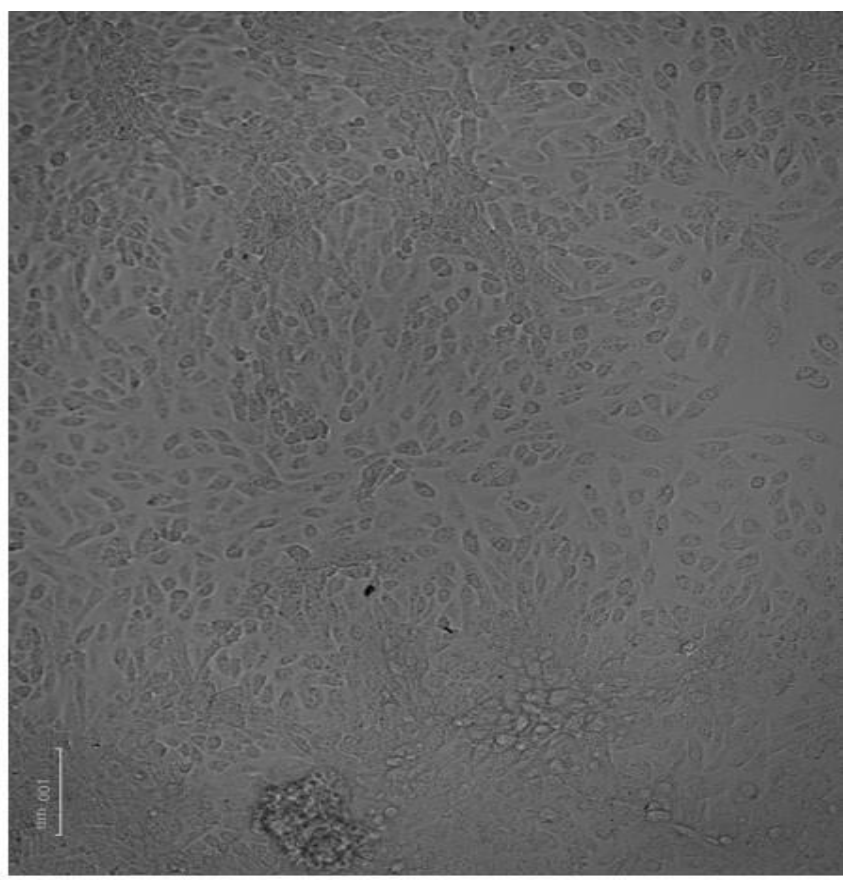

Fig 6: Formulation Showing Wound

Closure after 24 hrs 
Table 5: Densitometry Analysis of Wound Healing Assay for Control by Image J Software

\begin{tabular}{|c|c|c|c|l|}
\hline TIME & AREA & PERCENT & AREA & PERCENT \\
\hline $0 \mathrm{hr}$ & 10396.893 & & 10470.509 & \\
\hline $24 \mathrm{hr}$ & 84337.143 & 90.56 & 89203.679 & 83.54 \\
\hline
\end{tabular}

Table 6: Densitometry Analysis of Wound Healing Assay for Treated by Image J Software

\begin{tabular}{|c|c|c|c|c|}
\hline TIME & AREA & PERCENT & AREA & PERCENT \\
\hline $0 \mathrm{hr}$ & 10652.345 & & 10676.496 & \\
\hline $24 \mathrm{hr}$ & 159377.928 & 99.50 & 161653.473 & 97.68 \\
\hline
\end{tabular}

Table 7: Densitometry Analysis of Wound Healing Assay by Image J Software (24 hrs)

\begin{tabular}{|c|c|c|c|}
\hline SAMPLE DETAILS & \multicolumn{2}{|c|}{$\begin{array}{c}\text { PERCENTAGES OF WOUND } \\
\text { HEALING (IN }\end{array}$} & $\begin{array}{c}\text { MEAN VALUE } \\
\text { DUPLICATES) }\end{array}$ \\
\hline Control & 90.56 & 83.54 & 87.05 \\
\hline $\begin{array}{c}\text { Treated with } \\
130 \mu \mathrm{g} / \mathrm{ml} \text { of }\end{array}$ & 99.50 & 97.68 & 98.59 \\
Formulation & & & \\
\hline
\end{tabular}




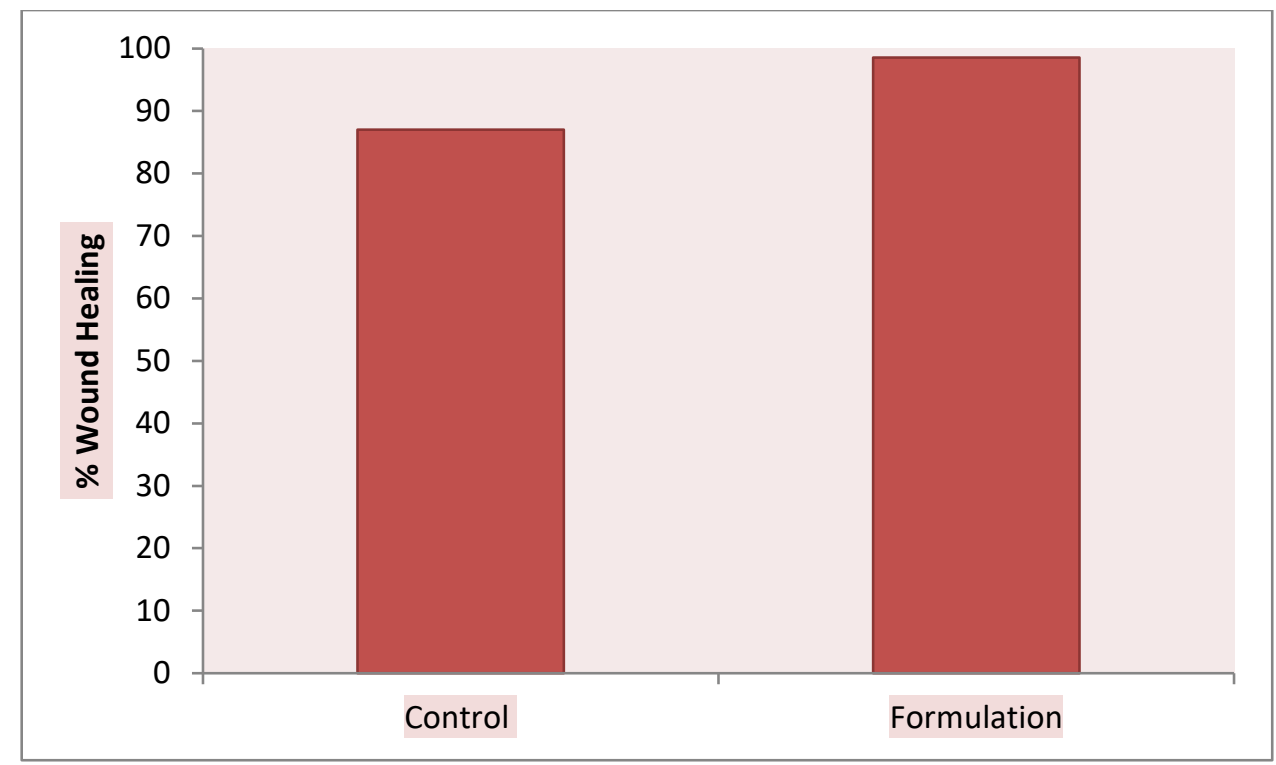

Fig 7: \% Wound Healing Of Control and Formulation

Cell cytotoxicity assay for the formulation was performed on Vero Cell lines. After $24 \mathrm{hrs}$ the cell viability effect of Formulation against Vero cell lines at different concentrations were determined using the MTT assay and the results have been summarized in Tables 25 and 26 and the control mean OD value is obtained as 0.481 from the Table 2. All concentrations of the sample does not induced cell cytotoxicity as illustrated from Table 4 and the 50 percentage inhibitory concentration (IC50) for the sample also determined as $130.5 \mu \mathrm{g} / \mathrm{ml}$ and given in Table 3 .

In vitro wound healing activity, Vero cells were treated with $130.5 \mu \mathrm{g} / \mathrm{ml}$ of formulation for $24 \mathrm{hrs}$. Cell migration at $0,24 \mathrm{~h}$ were captured and wound closure distance was calculated by Image $\mathbf{J}$ software and illustrated in Tables 5-7 and Fig 3-6. Percentage wound closure at different time intervals in untreated and F6 treated cells is $87.05 \%$ and $98.59 \%$ respectively, which have been represented from Fig. 7

\section{CONCLUSION}

This report demonstrated clearly that the formulation was effective in enhancing wound contraction. The cell cytotoxicity assay demonstrates that the formulation has no toxic effects to the cells. According to the in vitro data, the wound healing impacts of the formulation could be attributed to the regulation and coordination of inflammation, angiogenesis, and tissue regeneration. This research provides scientific proof that enzymatic formulation is indeed a promising wound healing therapy. The study demonstrates that the wound healing assay is a cost effective method that produces reliable and reproducible outcomes in a 
simulated wounded area. As a result, this approach would be used to acquire preliminary insights into the wound healing potential.

\section{REFERENCES:}

1. Schultz GS, Chin GA, Moldawer L, Diegelmann RF. 23 Principles of Wound Healing. Mechanisms of vascular disease: a reference book for vascular specialists. 2011:423.

2. Öhnstedt E, Lofton Tomenius H, Vågesjö E, Phillipson M. The discovery and development of topical medicines for wound healing. Expert opinion on drug discovery. 2019 May 4;14(5):485-97.

3. Velnar T, Bailey T, Smrkolj V. The wound healing process: an overview of the cellular and molecular mechanisms. Journal of International Medical Research. 2009 Oct;37(5):1528-42.

4. Kirsner RS, Eaglstein WH. The wound healing process. Dermatologic clinics. 1993 Oct 1;11(4):629-40.

5. Xu, L., and Deng, X. (2006) Protein Kinase C Promotes Nicotine-induced Migration and Invasion of Cancer Cells via Phosphorylation of - and m-Calpains* J. Biol. Chem. 281, 4457-4466.

6. XiaoyuYang, YiXu, TaoWang, DanShu, PeixuanGuo, Keith Miskimins,Steven Y.Qian. (2017). Inhibition of cancer migration and invasion by knocking down delta-5-desaturase in COX-2 overexpressed cancer cells. Redox Biology. 11, 653662

7. Bektas N, Şenel B, Yenilmez E, Özatik O, Arslan R. Evaluation of wound healing effect of chitosan-based gel formulation containing vitexin. Saudi Pharmaceutical Journal. 2020 Jan 1;28(1):87-94.

8. Liang CC, Park AY, Guan JL. In vitro scratch assay: a convenient and inexpensive method for analysis of cell migration in vitro. Nature protocols. 2007 Feb;2(2):329-33.

9. Martinotti S, Ranzato E. Scratch wound healing assay. InEpidermal cells 2019 (pp. 225-229). Humana, New York, NY.

10. Stamm A, Reimers K, Strauß S, Vogt P, Scheper T, Pepelanova I. In vitro wound healing assays-state of the art. BioNanoMaterials. 2016 May 1;17(1-2):79-87. 